\title{
Retraction Note: Ocean surface temperature simulation based on big data and accuracy of English translation of foreign trade vocabulary
}

\author{
Xingping Shi ${ }^{1}$
}

Published online: 18 November 2021

C) Saudi Society for Geosciences 2021

Retraction Note: Arabian Journal of Geosciences (2021) 14: 1786 https://doi.org/10.1007/s12517-021-08175-z

The Editor-in-Chief and the Publisher have retracted this article because the content of this article is nonsensical. The peer review process was not carried out in accordance with the Publisher's peer review policy. The author has not responded to correspondence regarding this retraction.

The original article can be found online at https://doi.org/10.1007/ s12517-021-08175-z.

Xingping Shi

sammi05272009@163.com

1 City College of Science and Technology, Chongqing University, Chongqing 402167, China 